\title{
Oestradiol enhances in vitro the histamine release induced by embryonic histamine-releasing factor (EHRF) from uterine mast cells
}

\author{
Roberta Cocchiara', Giuseppe Albeggiani, \\ Giovanna Di Trapani, Antonina Azzolina, \\ Nadia Lampiasi, Federico Rizzo, Lidia Diotallevi², \\ Luca Gianaroli ${ }^{3}$ and Domenico Geraci
}

Istituto di Biologia dello Sviluppo, CNR, Via Archirafi 20, 90123 Palermo, ${ }^{2}$ Medicina della Riproduzione, Villa Regina. Via Castiglione 115, Bologna, Italy and ${ }^{3}$ Clinique de Sterilité, Hôpital Cantonal Université de Genève. Genève, Switzerland

'To whom correspondence should be addressed

The relationship between maternal hormones and factors secreted by the implanting embryo is still controversial. We have analysed the in-vitro effect of oestradiol and human embryo-derived histamine-releasing factor (EHRF) on histamine release from rat uterine mast cells. Rat uterine mast cells which were preincubated with oestradiol and then challenged with human EHRF gave histamine release values two- to threefold higher than those without preincubation. The enhancement observed was time- and temperaturedependent. A similar enhancement was obtained with human sensitized basophils but not with rat peritoneal mast cells. Oestradiol, used as a direct challenge, did not induce any histamine release from either rat uterine or peritoneal mast cells, or from human sensitized basophils. Oestradiol preincubation also enhanced the histamine release induced by anti-IgE but did not enhance the histamine release induced by substance $P$ or compound $48 / 80$, two secretagogues that are not mediated by IgE. Moreover, uterine fragments derived from rats at various oestrus phases, with different amounts of endogenous oestrogen, were challenged in vitro with EHRF. The release of histamine by mast cells was higher at the proestrus and preimplantation phases than at dioestrus. All these findings suggest that the interaction of oestradiol with rat uterine mast cells was capable of enhancing in vitro the histamine releasing effect of EHRF.

Key words: EHRF/IgE/oestradiol/uterine mast cell

\section{Introduction}

Pregnancy depends on synchronized events, orchestrated by an early maternal-embryonal dialogue (Adinolfi, 1989). The local uterine changes occurring at the site of blastocyst implantation suggest that embryonic signals could be very important (Hore and Mehrotra, 1988; Weitlauf, 1989). The maternal-embryonal dialogue is very likely to be controlled by a sequence of neuro-hormonal events interacting with the immune system (Hall et al., 1989).

Previous results obtained by our group showed that embryonic histamine-releasing factor (EHRF) secreted by the human preimplantation embryo (Cocchiara et al., 1987a,b, 1988a) interacts with rat uterine mast cells in vitro causing release of histamine (Cocchiara et al., 1988b). Several studies (Brandon and Bibby, 1979; Hore and Mehrotra, 1988; Cocchiara et al., $1988 \mathrm{~b}$ ) report an increase of the number of rat uterine mast cells and of the total content of uterine histamine, reaching a maximum during the preimplantation stage and declining when embryo implantation is established. Moreover, the oestradiol concentration increases during the preimplantation stage in rats (Yoshinaga et al., 1969; Findlay, 1983; Hodgen and Itskovitz, 1989), and some studies suggest that the oestradiol is responsible for the degranulation of rat uterine mast cells and for the release of histamine in vivo (Spaziani and Szego, 1959; Green et al., 1964; Ferrando and Nalbandon, 1968; Gibbons and Chang, 1972). Conflicting results, as reviewed by Weitlauf (1989), are reported on the in-vivo role of histamine and mast cells, since Shelesznyak (1952) suggests that this vasoactive amine can play a key role in implantation and Spaziani and Szego (1959) suggest a decrease in the mast cell population and histamine content as a result of the rise in circulating maternal oestrogen. A role of uterine mast cells during implantation could be supported by recent data on the molecules secreted by mast cells in addition to histamine, such as cytokines (Galli et al., 1991; Fay and Grudzinskas, 1991) and prostaglandins (Kennedy, 1977; Toder et al., 1984; Loke, 1989).

Observations of this sort have led us to determine whether oestradiol can influence degranulation of rat uterine mast cells and whether a factor secreted by the implanting embryo could be involved in this process. The availability of EHRF preparations and of uterine mast cells makes it possible to test this hypothesis in vitro.

Materials and methods

\section{Buffers}

HEPES-buffered Tyrode's solution (10 mM HEPES, $137 \mathrm{mM}$ $\mathrm{NaCl}, 5.6 \mathrm{mM}$ glucose, $2.7 \mathrm{mM} \mathrm{KCl}, 0.4 \mathrm{mM} \mathrm{NaH} 2 \mathrm{PO}_{4}$. $1 \mathrm{mM} \mathrm{CaCl}_{2}, 1 \mathrm{mM} \mathrm{MgCl}$ ) with $0.3 \%$ bovine serum albumin (BSA) titrated to $\mathrm{pH} \mathrm{7.4,} \mathrm{was} \mathrm{used} \mathrm{for} \mathrm{the} \mathrm{histamine} \mathrm{release}$ experiments and for the collection of peritoneal cells. The same solution but free of calcium and magnesium ions, was used for tissue washing. Tris $-\mathrm{ACM}$ buffer $(0.025 \mathrm{M}$ Tris. $0.12 \mathrm{M} \mathrm{NaCl}$. 
$6 \times 10^{4} \mathrm{M} \mathrm{CaCl}_{2}, 0.001 \mathrm{M} \mathrm{MgCl}_{2}, \mathrm{pH} 7.4$ ) with added $0.3 \%$ BSA was used for the histamine release assay from atopic blood

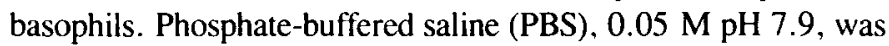
used in the histamine single isotope microassay.

\section{Materials}

Oestradiol was prepared at a concentration of $200 \mu \mathrm{g} / \mathrm{ml}$ (Sigma Chemical Co. Ltd, St Louis, MO, USA) in a stock solution containing Tyrode's buffer and $60 \mathrm{mg} / \mathrm{ml}$ BSA. Sheep anti-rat IgE was purchased from Tago Inc. (Burlingame, CA, USA). Both of the anti-IgE were used diluted by $1: 100$. S-Adenosyl-L-methyl$\left[{ }^{3} \mathrm{H}\right]$ methionine was purchased from Amersham Radiochemical Centre. UK. EHRF was isolated from human embryo culture supernatants by means of a heparin -Sepharose column and was prepared in our laboratory as previously described (Cocchiara et al., 1987a, 1988a) and used at a concentration of $1 \mathrm{mg} / \mathrm{ml}$. Briefly, $10 \mathrm{ml}$ obtained from 10 human embryo culture media (grown in vitro during an in-vitro fertilization programme) were loaded onto a heparin-Sepharose column. After washing, the EHRF activity was eluted with $0.5 \mathrm{M} \mathrm{NaCl}$. The activity was tested by histamine release assay, using human basophils from atopic donors. Compound 48/80 was obtained from Sigma and stored as a stock solution of $100 \mathrm{mg} / \mathrm{ml}$ in $1 \%$ dimethyl sulphoxide (DMSO).

\section{Animals and tissue source}

Wistar female rats ( 8 weeks old) were purchased from Morini (Reggio Emilia, Italy). The oestrus cycle was determined daily by analysis of vaginal smears for at least 9 days. The dark - light period during which mating occurred was designated night 0 of pregnancy, followed by day 1 (when mating plugs or vaginal spermatozoa were observed). The rats were killed and uteri were removed during different phases of the oestrus cycle or on different days of pregnancy, placed in cold Tyrode's solution, cleaned from adherent connective tissue and cut into pieces of $50 \mathrm{mg}$ wet weight by scissors. Uterine fragments were washed in $\mathrm{Ca}^{2+}$ - and $\mathrm{Mg}^{2+}$-free Tyrode's solution.

The peritoneal mast cells were collected by washing the peritoneal cavity with Tyrode's buffer supplemented with $0.3 \%$ BSA. They were washed in the same buffer and diluted to a final concentration of $350000 / \mathrm{ml}$. The basophils were obtained from venous blood of atopic donors, with their permission.

\section{Histamine release experiments}

The effect of histamine secretagogues on rat uterine fragments of peritoneal mast cells and human atopic blood basophils was determined. Rat uterine fragments were washed in Tyrode's buffer, $0.3 \%$ BSA final concentration. The samples were prewarmed for $10 \mathrm{~min}$ at $37^{\circ} \mathrm{C}$ and incubated at $37^{\circ} \mathrm{C}$ in Eppendorf tubes containing $20 \mu \mathrm{l}$ of each secretagogue, EHRF, anti-IgE or buffer alone. After $30 \mathrm{~min}$, the reaction was stopped by addition of $300 \mu \mathrm{l}$ cold Tyrode's buffer. Rat peritoneal mast cells were treated as reported previously (Cocchiara et al., 1988b). A $200 \mu \mathrm{l}$ volume of peritoneal cells at $350000 / \mathrm{ml}$ was incubated in Tyrode's solution with various secretagogues (anti-IgE, EHRF, substance $P$, compound $48 / 80$ ).

Aliquots of $200 \mu \mathrm{l}$ of whole human atopic heparinized blood were incubated with different secretagogues in $20 \mu \mathrm{l}$ of Tris -
$\mathrm{ACM}, 1 \times$ buffer. All the mixtures incubated at $37^{\circ} \mathrm{C}$ for $30 \mathrm{~min}$ were centrifuged in a Heraeus Sepatech Biofuge 17RS and triplicate aliquots of $20 \mu \mathrm{l}$ of plasma were then removed for the histamine assay.

When experiments with oestradiol were performed, uterine or peritoneal mast cells or basophils were preincubated with oestradiol $(1 \mu \mathrm{g} / \mathrm{ml})$ for $30 \mathrm{~min}$ and then challenged with the secretagogue for $30 \mathrm{~min}$. As a control, cells were preincubated with oestradiol for $30 \mathrm{~min}$ and challenged with buffer alone for $30 \mathrm{~min}$.

\section{Histamine release assay}

Histamine was assayed by a single isotope enzymatic microassay, as previously described (Taylor et al., 1980), by using $500 \mathrm{mCi} / \mathrm{mmol} \mathrm{S}$-adenosyl-L-methyl- $\left[{ }^{3} \mathrm{H}\right]$ methionine (SAM) and a crude preparation of rat kidney histamine-methyl-transferase (HMT) (Shaff and Beaven, 1979), as previously described (Taylor et al., 1980; Cocchiara et al., 1988a).

To each triplicate aliquot of supernatant $(20 \mu \mathrm{l})$ obtained after release experiments, $10 \mu \mathrm{l}$ of HMT-SAM solution was added and the tubes, after a gentle mixing, were incubated at $37^{\circ} \mathrm{C}$ for $1 \mathrm{~h}$. The reaction was stopped with $10 \mu \mathrm{l}$ of $1 \mathrm{~N} \mathrm{NaOH}$, and the $\left[{ }^{3} \mathrm{H}\right]$ methyl-histamine formed was extracted into $250 \mu \mathrm{l}$ of chloroform. After centrifugation at $3000 \mathrm{~g}$ for $5 \mathrm{~min}$, the aqueous phase was removed and the organic phase washed with $100 \mu \mathrm{l}$ of $\mathrm{NaOH}(1 \mathrm{M})$ saturated with $\mathrm{NaCl}$. After centrifugation, $150 \mu \mathrm{l}$ of the organic phase was transferred to a scintillation vial and evaporated to dryness. The liquid scintillator was added and the bound radioactivity determined in a Beckman counter. The total histamine was determined by boiling the cells or the tissue fragments for $10 \mathrm{~min}$ with $0.05 \mathrm{M}$ phosphate buffer ( $\mathrm{pH} 7.9$ ). Spontaneous release was calculated by incubating the cells or the tissue with buffer alone. The level of histamine release was expressed as a percentage of the total histamine after subtraction of the level of spontaneously released histamine. The enhancement of histamine release was calculated using the following formula: (histamine release with stimulus plus oestradiol histamine release with stimulus)/total histamine content.

\section{Statistical analysis}

Data were expressed as mean \pm SEM of at least four repeated experiments. The experiments were performed in triplicate and the intra-assay SEM did not exceed 5\%. One-way analysis of variance (ANOVA) was used to determine differences between groups. When differences existed, the ANOVA analysis was followed by the two-tailed (unpaired) Student's $t$-test.

\section{Results}

\section{Oestradiol-induced enhancement of histamine release in response to stimulation with anti-IgE}

The effect of oestradiol on histamine release was initially analysed using human basophils and anti-human IgE since this is a convenient experimental model. Kinetic experiments showed that oestradiol preincubation enhanced the histamine release in response to stimulation with anti-IgE in a time-dependent manner. The enhancement obtained after $60 \mathrm{~min}$ of oestradiol pre- 
incubation was twofold higher $(50 \%)$ than after preincubation for $0 \mathrm{~min}(27 \%)$ (Figure 1). The same cells, preincubated for different time periods with buffer instead of oestradiol released the same amount of histamine on challenge with anti-IgE (Figure 1). Histamine release was not observed when the basophils were preincubated with oestradiol but without any anti-lgE challenge (Figure 1). The statistical significance of the oestradiol enhancement was evaluated in experiments performed with basophils from 12 atopic subjects. The variability between the group means shown in Table I (anti-IgE and oestradiol + anti-IgE) was significantly larger than the average variability within the different treatment groups. There were very significant differences among the groups $(P=0.0023$ ). Moreover, analysis using ANOVA was identical to results of the unpaired two-tailed $t$-test.

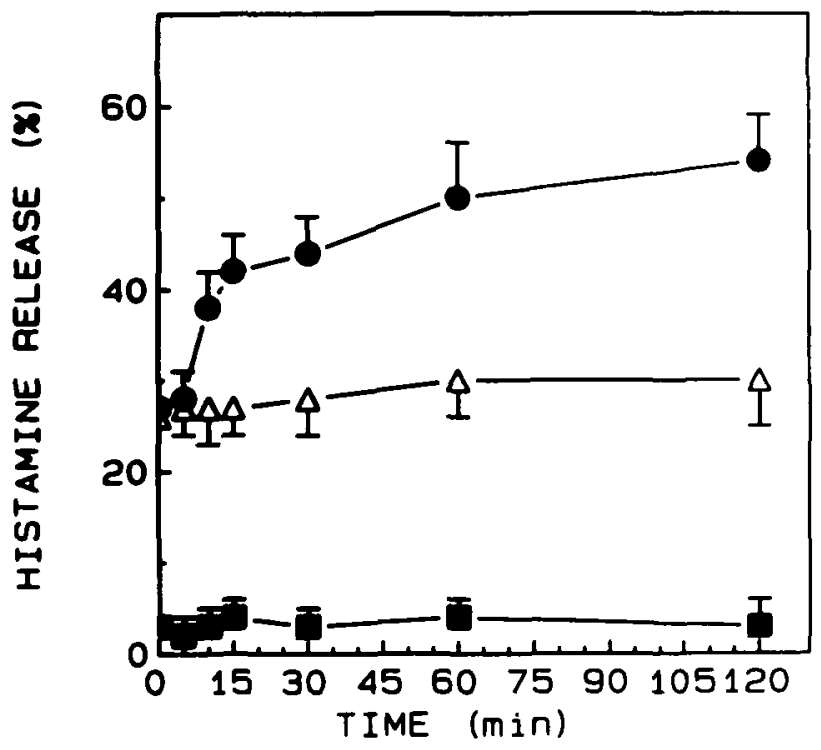

Fig. 1. Time-dependent enhancement of histamine release by oestradiol from leukocytes (human basophils). The cells were preincubated with $1 \mu \mathrm{g} / \mathrm{ml}$ of oestradiol $(\bullet)$ or buffer $(\Delta)$ for various times and then stimulated with anti-IgE (1:100) for $30 \mathrm{~min}$ The values of histamine release obtained by challenge with oestradiol are also reported ( $\square$ ). Data are the mean \pm SEM of four separate experiments.
Similar results were obtained using rat peritoneal mast cells (data not shown) and rat uterine fragments as the source of mast cells instead of human basophils.

Three representative experiments showing significant enhancement of histamine release upon preincubation with oestradiol and subsequent challenge with anti-IgE are reported in Table II $(P<0.01)$.

\section{Oestradiol-induced enhancement of histamine release in response to stimulation with $\mathrm{EHRF}$}

The rat mast cells and the human basophils were preincubated with oestradiol and then challenged with EHRF. The uterine mast cells obtained from 30 rats gave a histamine release induced by EHRF of $14 \pm 4 \%$. This release was always enhanced by preincubation with oestradiol, giving a value of $26 \pm 7 \%$ (Figure 2). Human basophils from seven atopic donors showed histamine release values when challenged with EHRF of $15 \pm 5 \%$, which increased to $37 \pm 9 \%$ when preincubated with oestradiol. The peritoneal mast cells did not release histamine when challenged with either EHRF or oestradiol + EHRF. The standard deviation among the values obtained from different subjects was quite high, suggesting that each subject had a different sensitivity. However, the values obtained in the presence of oestradiol were significantly higher than the controls without the oestradiol preincubation $(P<0.01)$

To evaluate whether there was any correlation between the in-vitro histamine release results and the in-vivo oestrogen variation, the following experiments were performed. Two different phases of the reproductive cycle were analysed: proestrus, when the oestradiol concentration was maximal and dioestrus, when oestradiol is absent or at a very low level. In addition, we analysed day 4 of pregnancy (preimplantation stage), when the oestradiol reaches the maximum concentration during pregnancy. At proestrus, the histamine release induced by anti-IgE and EHRF was $16 \pm 3 \%$ and $18 \pm 4 \%$ respectively. These values were higher than the values obtained in dioestrus when the histamine release by either anti-IgE or EHRF challenge was only $6 \%$. At the preimplantation stage, the histamine release induced by anti-IgE was $16 \pm 4 \%$ and by EHRF $31 \pm 6 \%$

\begin{tabular}{|c|c|c|c|c|c|}
\hline Donors & $\begin{array}{l}\text { Spontaneous histamine release } \\
\mathrm{ng} / \mathrm{ml} \pm \mathrm{SEM}\end{array}$ & $\begin{array}{l}\text { Total histamine } \\
\mathrm{ng} / \mathrm{ml} \pm \mathrm{SEM}\end{array}$ & $\begin{array}{l}\text { Anti-IgE } \\
\mathrm{ng} / \mathrm{ml} \pm \operatorname{SEM}(\%)\end{array}$ & $\begin{array}{l}\text { Oestradiol }+ \text { antı-lgE } \\
\mathrm{ng} / \mathrm{ml} \pm \mathrm{SEM}(\%)\end{array}$ & $\begin{array}{l}\text { Enhancement } \\
(\%)\end{array}$ \\
\hline 1 & $16 \pm 1.3$ & $92.7 \pm 5$ & $29.55 \pm 3 \quad(17)$ & $45.5 \pm 3.2$ & 17 \\
\hline 2 & $33 \pm 2$ & $147 \pm 3.2$ & $79.6 \pm 4.2(40)$ & $124 \pm 9.6(80)$ & 30 \\
\hline 3 & $242 \pm 4$ & $249 \pm 10.5$ & $448 \pm 2.5(9)$ & $1033 \pm 11.1(35)$ & 23 \\
\hline 4 & $22 \pm 5.2$ & $170 \pm 9.7$ & $\pm 7.3(66)$ & $138 \pm 95(78)$ & 10 \\
\hline 5 & $20 \pm 4.3$ & \pm 15.3 & $73.4 \pm 4.1(37)$ & $116.8 \pm 8.7$ & 26 \\
\hline 6 & $11.7 \pm 1.2$ & \pm 9.2 & $\pm 1.8(16)$ & $88 \pm 5.2(61)$ & 41 \\
\hline 7 & $26 \pm 1.5$ & \pm 11.2 & $80.3 \pm 6.2(22)$ & $113 \pm 9.3$ & 12 \\
\hline 8 & $28 \pm 1.3$ & \pm 6.1 & $\pm 5.5(55)$ & $126 \pm 8$ & 24 \\
\hline 9 & $24 \pm 1.6$ & \pm 5.8 & $\pm 4.9(30)$ & $92.5 \pm 4$ & 20 \\
\hline 10 & $12 \pm 11$ & \pm 6.9 & $\pm 3.2(37)$ & $70.4 \pm 8.2$ & 18 \\
\hline 11 & $7.4 \pm 0.9$ & $115 \pm 7.4$ & $\pm 2.8(45)$ & $72.5 \pm 4.3 \quad(59)$ & 25 \\
\hline 12 & $11 \pm 1$ & $129 \pm 58$ & $403 \pm 3.4(27)$ & $607 \pm 5.2$ & 16 \\
\hline
\end{tabular}

Values of histamine release are expressed as $\mathrm{ng} / \mathrm{ml}$ (mean \pm SEM of triplicate experiments). The percentage histamine release [ındıcated as (\%)] with oestradiol plus anti-lgE was significantly higher $(P<0.01)$ than data obtained with anti-IgE alone. 
Table II. Effect of oestradıol preincubation on the enhancement of histamine release induced by ant1-IgE from uterine fragments

\begin{tabular}{lllll}
\hline Experiment & $\begin{array}{l}\text { Oestradiol } \\
\text { preincubation }\end{array}$ & $\begin{array}{l}\text { Anti-IgE } \\
\text { release }\end{array}$ & $\begin{array}{l}\text { Histamine } \\
\text { release, \% }\end{array}$ & \pm SEM \\
\hline I & + & - & 15 & \pm 007 \\
& - & + & 18.6 & \pm 15 \\
II & + & + & 34.1 & \pm 2.7 \\
& + & - & 1.7 & \pm 0.9 \\
& - & + & 151 & \pm 1.2 \\
III & + & - & 302 & \pm 2.2 \\
& + & + & 1.3 & \pm 0.07 \\
& + & + & 2.6 & \pm 0.8 \\
& + & & & \pm 1.8 \\
\hline
\end{tabular}

Uterine fragments were $(+)$ or were not $(-)$ preıncubated with $1 \mu \mathrm{g} / \mathrm{ml}$ oestradıol for $30 \mathrm{~min}$ and then challenged with anti-IgE. Results are the mean \pm SEM of triplicate experiments The histamine release obtained in the presence of oestradıl was significantly higher $(P<0.01)$ than the control without oestradiol.

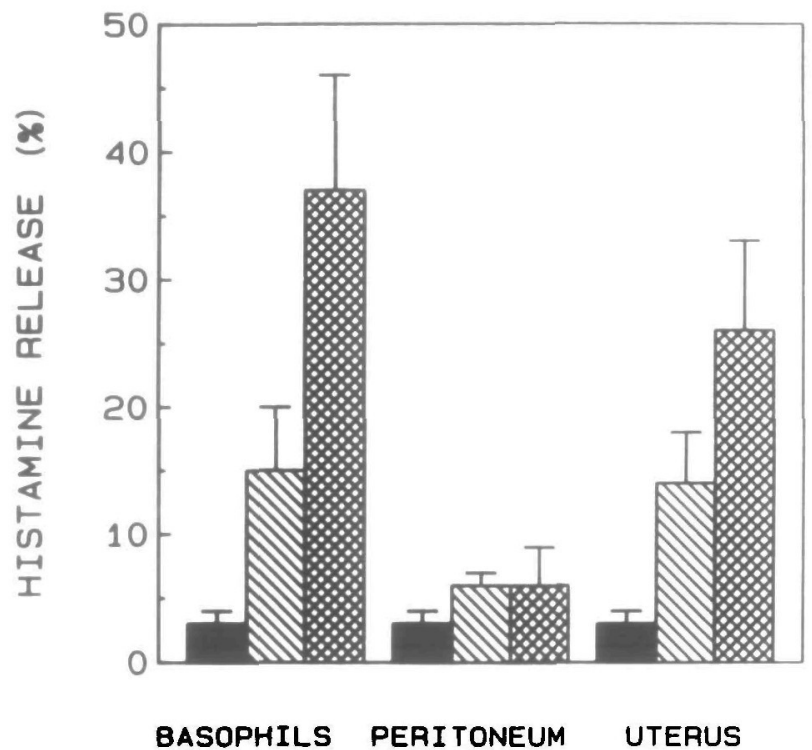

Fig. 2. Etfect of oestradiol preincubation on EHRF-induced histamine release from basophils, peritoneal mast cells and uterine fragments. Cells were preincubated ( or not preincubated (\$) with $1 \mu \mathrm{g} / \mathrm{ml}$ oestradiol for $30 \mathrm{~min}$ and stimulated with EHRF for $30 \mathrm{~min}$. Values of histamine release obtained with oestradiol alone (a) are also shown. The data are expressed as mean \pm SEM of different experiments. The values from basophils and uterine fragments of EHRF-induced histamine release after preincubation with oestradiol were significantly higher than the control without preincubation $(P<0.01)$.

(Figure 3). As a control, oestradiol used alone did not induce any histamine release from the uterine fragments (Figure 3 ).

In experiments designed to understand the mechanism(s) involved in the enhancement of the histamine release by oestradiol, we found that the effect was temperature dependent in the same fashion as the anti-IgE-induced histamine release (Table III).

\section{Histamine release induced by substance $P$ and compound 48/80 was not enhanced by oestradiol}

Two non-IgE mediated secretagogues, such as substance $P$ and compound $48 / 80$, were used instead of the anti-IgE, to evaluate

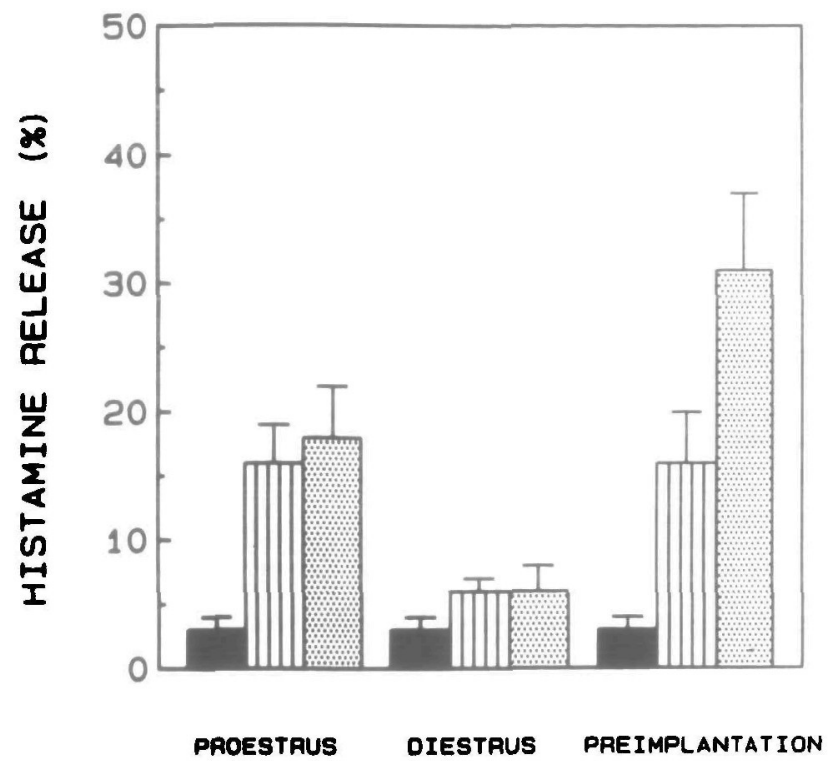

Fig. 3. Effect of oestradiol on histamine release by uterine fragments during the different phases of the reproductive cycle. Uterine fragments at proestrus, dioestrus and preimplantation phase (day 4 of pregnancy) were stimulated with oestradiol ( $\mathbf{a}$ ), anti-IgE (四) or EHRF (1) for 30 min. The results are the mean \pm SEM of five different experiments.

Table III. Different effects of oestradiol preincubation on peritoneal mast cells stimulated with anti-IgE. substance $P$ or compound $48 / 80$

\begin{tabular}{lrc}
\hline & \multicolumn{3}{c}{ Histamine release } \\
\cline { 2 - 3 } & $(\mathrm{ng} / \mathrm{ml} \pm \mathrm{SEM})$ & $(\%)$ \\
\hline Spontaneous release (Tyrode's) & $6.25 \pm 0.5$ & - \\
Oestradiol $(1 \mu \mathrm{g} / \mathrm{ml})$ & $7.3 \pm 0.9$ & 1.2 \\
Tyrode's + ant1-IgE & $27.0 \pm 1.8$ & 25.0 \\
Oestradiol $(1 \mu \mathrm{g} / \mathrm{ml})+$ anti-IgE & $46.0 \pm 2.3$ & 48.0 \\
Oestradıl $(1 \mu \mathrm{g} / \mathrm{ml})\left(4^{\circ} \mathrm{C}\right)+$ anti-IgE $\left(4^{\circ} \mathrm{C}\right)$ & $6.0 \pm 0.4$ & 0 \\
Oestradıl $(1 \mu \mathrm{g} / \mathrm{ml})\left(4^{\circ} \mathrm{C}\right)+$ anti-IgE $\left(37^{\circ} \mathrm{C}\right)$ & $25.6 \pm 0.5$ & 24 \\
Substance $\mathrm{P}(25 \mu \mathrm{M})$ & $54.6 \pm 2.2$ & 590 \\
Oestradiol $(1 \mu \mathrm{g} / \mathrm{ml})+$ substance $\mathrm{P}(25 \mu \mathrm{M})$ & $41.6 \pm 1.9$ & 430 \\
Compound $48 / 80(10 \mu \mathrm{g} / \mathrm{ml})$ & $39.0 \pm 0.7$ & 40.0 \\
Oestradiol $(1 \mu \mathrm{g} / \mathrm{ml})+$ compound $48 / 80$ & $375 \pm 1.4$ & 38.0 \\
Total histamıne & $88.0 \pm 2.1$ & \\
\hline
\end{tabular}

Peritoneal mast cells were or were not preincubated $\left(37^{\circ} \mathrm{C}\right)$ with oestradiol $(1 \mu \mathrm{g} / \mathrm{ml})$ for $30 \mathrm{~min}$ and then challenged with ant $-\mathrm{IgE}$, substance $\mathrm{P}$ or compound $48 / 80$ Controls comprised cells preincubated with oestradiol at $4^{\circ} \mathrm{C}+$ anti- $\mathrm{IgE}$ at $4^{\circ} \mathrm{C}$ or with oestradiol at $4^{\circ} \mathrm{C}+$ anti- $\mathrm{IgE}$ at $37^{\circ} \mathrm{C}$. The results are expressed as $\mathrm{ng}$ of histamine released per $\mathrm{ml}$ of assay $(n=3)$. The percentage of total histamine was calculated after subtraction of spontaneous release.

whether the IgE molecules were involved in the oestradiolmediated enhancement. When different concentrations of oestradiol and substance $P$ or compound $48 / 80$ were used, no enhancement of histamine release was detected. These results are summarized in Table III where the results with only one concentration of oestradiol $(1 \mu \mathrm{g} / \mathrm{ml})$ and secretagogue are shown. The standard deviation among the results obtained from different individuals was quite high, suggesting that each had a different sensitivity. However, the values obtained in the presence of oestradiol were significantly higher than the controls made without oestradiol preincubation $(P<0.001)$. 
The effect of oestradiol on the enhancement of mast cell histamine release induced by EHRF and anti-IgE was not observed when two non-IgE mediated secretagogues, such as compound $48 / 80$ and substance $P$, were used. Therefore, these data suggest that the oestradiol was probably involved in the exposition of receptors of the $\mathrm{IgE}$ molecule present on the basophil and mast cell surface and specifically interacting with EHRF and anti-IgE. In addition, this finding provides evidence that a signal from the human embryo (EHRF) could interact with $\mathrm{IgE}$ molecules present on the surface of the maternal uterine cells.

Oestradiol, although capable of enhancing histamine release induced by specific secretagogues, was not capable of directly inducing histamine release in vitro. This result is in contrast with the in-vivo data reported in the literature. As is well known, the endogenous oestradiol concentration changes during the oestrus cycle. Several workers suggest that the mast cell population and the histamine content decrease as a result of circulating oestrogen (Levier and Spaziani, 1966; Gibbons and Chang, 1972).

A relationship between the number of uterine mast cells and the different phases of the reproductive cycle has been established in vivo (Gibbons and Chang, 1972; Brandon and Bibby, 1979; Brandon and Evans, 1983). The number increases from day 3 to day 4 of pregnancy and then decreases around the time of blastocyst attachment (De Feo, 1967; Brandon and Bibby, 1979).

\section{Discussion}

The present study demonstrates that oestradiol preincubation in vitro enhances the histamine-releasing action of EHRF as well as anti-IgE on human basophils and rat uterine mast cells. The histamine release from the uterine mast cells induced by EHRF was higher at the proestrus and preimplantation stages of the reproductive cycle than at dioestrus.

Previous studies made by our group showed that pre-embryos growing in vitro produce a histamine-releasing factor (EHRF) from the 2-cell to the 8-cell stage in humans (Cocchiara et al., $1987 \mathrm{a}, \mathrm{b}, 1988 \mathrm{a}, \mathrm{b})$, and from the 2-cell to the blastocyst in rats (preliminary results), and it was active as a histamine releaser in human basophils and rat uterine mast cells. The human and rat EHRF showed similar activity and there was cross-species reactivity. The latter is not surprising or unusual, since it has been reported in the literature and confirmed by several laboratories that $\mathrm{IgE}$ receptors in human cultured basophils bind both human and rodent IgE with comparable affinity (Ishizaka et al., 1985).

The human EHRF, while capable of inducing histamine release from human basophils and rat uterine mast cells, was inactive when rat peritoneal mast cells were used as the target cells. A tentative explanation could be that the local environment or tissue-specific differences in differentiation might modify the cell surface specificity, resulting in mast cell heterogeneity, as reported in the literature (Befus, 1986).

The rat uterine mast cells preincubated with oestradiol and then challenged with human EHRF gave histamine release values which were two- to threefold higher than values obtained without preincubation. Brandon and Bibby (1979) observed that the number of mast cells increases during the pre-attachment phase of pregnancy to reach a maximum around the time of blastocyst attachment and then decreases during the attachment phase of pregnancy. They claim that the reduction in mast cell number occurred both within and between attachment sites, suggesting the presence of a stimulus of maternal origin. However, more recently Hore and Mehrotra (1988) clearly demonstrated that the fall in the mast cell number in implanting sites was higher than in the interimplantation area. Therefore, a factor, or the presence of the blastocyst itself could cause the localized cell depletion.

The results reported in this paper strongly suggest that, in vitro, oestradiol used alone or as a secretagogue is completely inactive. Moreover, when uterine tissue fragments from rat uteri at different oestrus phases were used, different results were obtained. The endogenous oestradiol concentration was higher at proestrus and during the preimplantation stage and lower at dioestrus. When the uterine fragments containing mast cells were collected at proestrus or at the preimplantation stage and then challenged with EHRF in vitro, the resulting histamine release values were higher than at dioestrus stage. A tentatıve explanation is that the uterine mast cells in a milieu with a higher oestradiol concentration become more reactive on exposure to the EHRF challenge. The coincidence of the timing of the higher concentration of oestradiol during the preimplantation phase, the number of mast cells and the EHRF secretion by the preimplantation embryo, would suggest a probable in-vivo role of the combined action of oestradiol and EHRF. The high number of target uterine mast cells during the preimplantation stage would amplify the EHRF message sent by the implanting embryo, by the secretion of molecules contained in the mast cells. However, the percentage of enhancement of the histamine release by oestradiol, found at the preimplantation and proestrus phases, cannot depend on the higher mast cell concentration, since the number of mast cells found at proestrus was quite similar to or lower than at dioestrus.

Of particular interest could be the data reported in this paper on the in-vitro effect of oestradiol and EHRF on uterine mast cells, which may support an in-vivo role during embryo implantation of EHRF and uterine mast cells. The data could also help to clarify the relationship between maternal hormones and the factor(s) secreted by the implanting embryo.

\section{Acknowledgements}

This work was supported by a grant from the Natıonal Research Council $(\mathrm{CNR})$; targeted project 'Prevention and Control Discase Factors": subproject 'Control of Human Fertility'.

\section{References}

Adinolfi.M. (1989) In Stern.C (ed.). Immunology of Pregnamey and its Disorder Kluwer Academic Publishers. London. pp. 33-59.

Befus.A.D. (1986) Mast Cell Differentiation and Heterogenetry Raven Press. New York.

Brandon.J.M. and Bibby.M.C. (1979) A study of changes in uterıne mast cells during an early pregnancy in the rat. Biol. Reprod., 20. 977-989.

Brandon.J.M. and Evans.J.E. (1983) Uterine mast cells during the estrous cycle in the Syrian hamster. Am. J. Anat. 167. 241-247.

Cocchiara,R.. Di Trapanı.G.. Azzolina.A.. Albeggıanı.G.. Ciriminna.R.. Cefalú.E. Cittadini.E and Geraci.D (1987a) Isolation of a histamine releasing factor from human embryo culture medium after in vitro fertilization. Hum. Reprod. . 2. 341-344

Cocchiara.R. . Dı Trapani.G.. Azzolına.A . Albeggıan.G. and Geraci.D 
(1987b) Isolation of a histamıne-releasing factor from two-cell human embryo. Int. Arch. Allergy Appl. Immunol., 84, 32I-323.

Cocchiara.R.. Di Trapani.G.. Azzolina.A.. Albeggiani.G. and Geraci.D. (1988a) Identification of a histamine releasing factor, secreted by human pre-implantation embryos grown in vitro. J. Reprod. Immumol., 31. $41-52$.

Cocchıara.R.. Albeggiani,G.. Di Trapani,G.. Azzoina.A . Lampiasi.N.. Cervello,G. and Geraci,D. (1988b) Dispersal of rat uterıne mast cells and their functional response to an embryo-derived histamıne releasing factor: a possible model for embryo implantation. J. Reprod. lmmunol., 14, 191-201.

De Feo.V.J. (1967) Decidualization. In Wynn.R.M. (ed.). Cellular Biology of the Uterus. Appleton-Century Croft. New York. pp. $191-290$.

Fay,T.N. and Grudzinskas,J.G. (1991) Human endometrial peptides: a review of their potential role in implantation and placentation. Hum. Reprod., 6. $1311-1326$.

Ferrando.G. and Nalbandon,A.V. (1968) Relative importance of histamine and oestradiol on implantation in rat. Endocrinology. 83. $933-937$.

Findlay,J.K. (1983) The endocrinology of the preimplantation period. Curr. Top. Exp. Endocrinol., 4, 35.

Galli.J.S. . Gordon.J.R. and Wershill,B.K. (1991) Cytokıne production by mast cells and basophils. Curr. Opin. Immunol., 3, 865-873.

Gibbons.A.F.E. and Chang.M.C. (1972) Number of mast cell in the rat uterus with special reference to its relation to hormonal treatment and decidual response. Biol. Reprod., 6, 193-203.

Green.P.J.. Fram.H.D. and Kase.N. (1964) Methylhıstamine and histamine in the urine of women during the elaboratıon of oestrogen. Nature, 204, 1165-1168.

Gregory.C D. . Lee,H. . Scott.I.V., Shah.L.P. and Goldin.P.R. (1985) Cytotoxic reactivity of human natural killer (NK) cell durıng normal pregnancy: a longitudınal study. J. Clin. Lab. Immunol., 18 , $175-182$.

Hall,N.R.S., O'Grady,M.P., Steiner,C.R., Roth,L.C. and Goldstein, A.L. (1989) In Lakoski.J.M. . Parez-Polo.J.R. and Rassin,D.K. (eds), Neural Control of Reproductive Function. Alan R.Liss. New York. pp. $311-322$.

Hodgen.G.D. and Itskovitz.J. (1989) Recognition and maintenance of pregnancy. In Nobil.E.K. and Neil,J.D. (eds), The Physiology of Reproduction, Vol. 1. Raven Press, New York, pp. 1995-2021.

Hore,A. and Mehrotra,P.N. (1988) Presence of a blastocyst and mast cell depletion of the mouse uterus. Acta Anat., 132, 6-8.

Ishizaka,T., Dvorak.ann.M., Conrad,D.H., Nieybyl,J.R., Marquette, J.P. and Ishizaka,K. (1985) Morphologic and Immunological characterization of human basophils developed in cultures of cord blood mononuclear cells. J. Immunol., 134. 532-540.

Johnson,D.C. and Dey.S.K. (1980) Role of histamine in implantation dexamethasone inhibits estradiol-induced implantation in the rat. Biol Reprod., 22, 1136-1141.

Kennedy.T.G. (1977) Evidence for a role for prostaglandins in the initiation of blastocyst implantation in the rat. Biol. Reprod., 6 , $286-291$

Levier,R.R. and Spazıani,E. (1966) The effect of estradiol on the occurrence of mast cell in the rat uterus. Exp. Cell Res., 41. 244-252.

Loke, Y.W. (1989) In Stern.C. (ed.), Immunology of Pregnancy and its Disorders. Kluwer Academic Publishers. London, pp. 61-89.

Shaff, R.E. and Beaven,M.A. (1979) Increased sensitivity of the enzymatic isotopic assay of histamine: measurement of histamine in plasma and serum. Anal. Biochem., 94, 425-430.

Shelesnyak.M.C. (1952) Inhibition of decidual cell formation in the pseudopregnant rat by histamine antagonists. Am. J. Physiol., 170. $522-527$.

Spazıani,E. and Szego,C.M. (1959) Further evidence for mediation by histamine of oestradiolic stımulation of the rat uterus. Endocrinology, 64. $713-723$.
Taylor.K.M.. Krilıs.S. and Baldo.B.A. (1980) An enzymatic isotopic microassay for measuring allergic release of histamine from blood and mast cells in vitro. Int. Arch. Allergy Appl. Immunol., 61, 19-27.

Toder,V., Nebel,L. and Gieıcher,N. (1984) Studies of natural killer cells in pregnancy analysis at the single cell level. J. Clin. Lab. Immunol., 14. $123-127$.

Weitlauf.H.M. (1989) In Knobil.E. and Neill,J.D. (eds), The Physiology of Reproduction. Raven Press, New York, pp. 231-262.

Yoshinaga.K., Hawkins, R.A. and Stocker,J.F. (1969) Estrogen secretion by the rat ovary in vivo during the estrous cycle and pregnancy. Endocrinology, 85. 103-112.

Received on July 4, 1991; accepted on May 29, 1992 